\title{
GENERALIZATIONS OF THE STANDARD TRAVELLING SALESMAN PROBLEM
}

The Standard Travelling Salesman Problem (STSP) is to find a minimal closed tour of a weighted graph. A number of procedures have been developed for solving the STSP but there is no known one which grows less than exponentially with the number of nodes of the graph. The STSP has many applications to scheduling theory, vehicle routing, the implementation of algorithms in complex computing machines, the construction of information systems, etc., and to meet additional requirements of some of these applications the STSP has been generalized in many ways. Most of the problems which can be considered as generalizations of the STSP are to find the optimal routes for a group of salesmen provided the routes satisfy a set of requirements. Then a given generalization is obtained by specifying meanings of the terms "optimal", "a group of salesmen", and "a set of requirements imposed on routes".

One of the aims of this note* is to present a family of generalizations of the STSP which correspond to all meanings of the above-mentioned terms introduced so far and known to the author. Some problems are reducible to others, in particular, to the STSP, but there are only a few simple generalizations which are not NP-complete. The STSP is closely related to the assignment problem (AP) which has also been generalized in many ways, for instance as the multi-index problem or as the independent assignment problem. Thus the following question arises: how the generalizations of the STSP are related to those of the AP.

1. In the Travelling Salesman Problem we are given a non-negative integer $n$ and an $n$-dimensional square distance matrix $D=\left(d_{i j}\right)$ or, equivalently, we are given an $n$-node complete network. Any sequence $t=\left(i_{1}, i_{2}, \ldots, i_{p}, i_{1}\right)$ of integers from $\{1,2, \ldots, n\}$, which contains each of the $n$ integers at least once, and the first and last integers of which are identical, is called a tour. A tour is a feasible solution to the travelling

* The paper was presented at the IX International Symposium on Mathematical Programming, August 23-27, 1976, Budapest, Hungary. 
salesman problem and an optimal solution is a tour such that

$$
z(t)=\sum_{(i, j) \in t} d_{i j}
$$

is minimized, where

$$
t=\left[\left(i_{1}, i_{2}\right),\left(i_{2}, i_{3}\right), \ldots,\left(i_{p-1}, i_{p}\right),\left(i_{p}, i_{1}\right)\right] .
$$

This formulation of the problem can be found in many papers and the problem will be referred to hereafter as the Standard Travelling Salesman Problem (STSP) since it is closely related to the application which is given in the name: find the shortest closed path of a salesman who must visit all cities of a network.

Let us suppose that the matrix $D$ is feasible for the STSP, i.e., it does not produce any closed path of negative length.

Most generalizations of the STSP, which are very often called multisalesmen problems, are concerned with the minimization of the length of a tour which is required to satisfy some additional requirements.

Let us review some properties of optimal tours for the STSP. The following theorem is well known:

THEOREM 1. If $D$ satisfies the triangle inequality, then there is an optimal tour which visits each node once and only once.

If $D$ is an arbitrary matrix, we can apply this theorem to the matrix $D^{*}=\left(d_{i j}^{*}\right)$, where $d_{i j}^{*}$ is the length of the shortest path from $i$ to $j$, and then an arc $\left(i_{p}, i_{q}\right)$ of an optimal tour under $D^{*}$ represents the shortest path from $i_{p}$ to $i_{q}$ under $D$. Hence

COROLLARY 1. An optimal tour contains no arc $\left(i_{p}, i_{q}\right)$ for which there exists an $i_{r}$ such that $d_{i_{p} i_{r}}+d_{i_{r} i}<d_{i_{p} i_{q}}$.

Therefore, we can eliminate from considerations those ares which do not satisfy the triangle inequality and, furthermore, in certain cases the STSP may be treated as the General Routing Problem (GRP) which is to find a minimal tour traversing each arc in a required subset of arcs of the network and visiting each node in a required subset of nodes of the network. The STSP and the Chinese Postman Problem (CPP) are special cases of the GRP. Any feasible tour of the STSP on a graph can be considered as an Euler tour on a multigraph derived from a subgraph of the graph. Euler tours are simply characterized and easily identified, while no efficient and elegant characterization of Hamiltonian cycles has been obtained. It has been pointed out by Orloff [8]-[10] that the GRP approach can be more efficient than that of the STSP, since the GRP takes more advantage of the special structure of a network.

We can easily prove the existence of an optimal tour of the STSP which has the following properties: 
PROPERTY 1. There is an optimal tour such that each its elementary subtour (i.e., a closed path without multiple arcs) contains a node of degree 2.

COROLLARY 2. There is an optimal tour which contains a node of degree 2.

PROPERTy 2. There is an optimal tour which contains less than $2 n$ arcs.

Thus, in fact, an optimal solution to the STSP is that to the following multisalesmen problem:

Problem (P1). A salesman is required to visit each of $n-1$ "customer" nodes from a "base" node (which is not fixed a priori). During his travel he is allowed to return to the base. It is required to find such a base node which minimizes the number of the base visits and the total distance travelled by the salesman.

By Corollary 2, there are an optimal solution and a base which is visited exactly once.

Note that for a fixed node a tour can be considered as the union of elementary subtours. Notwithstanding, there is no need to introduce different salesmen for different elementary subtours in the case of the STSP with the optimality criterion of form (1). Simply, we may allow the salesman to visit the base node during his travel. However, if $D$ is a time matrix, then we can state the following

Problem (P2). There are $m$ salesmen available at a "base" node (which is not fixed a priori) who are required to visit $n-1$ "customer" nodes and return to the base node. The problem is how many of the $m$ salesmen should be used to minimize the time of travelling, i.e., to minimize

$$
y(t)=\min _{1 \leqslant k \leqslant n} \max _{\left\{v_{s}\right\}_{k}} \sum_{(i, j) \in v_{s}} d_{i j}
$$

where $\left\{v_{s}\right\}_{k}$ is the set of elementary subtours of $t$ with respect to node $k$ $(k=1,2, \ldots, n)$.

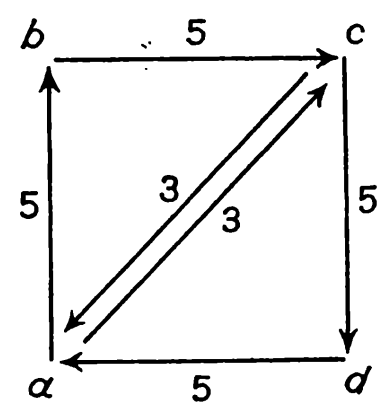

Fig. 1

Fig. 1 shows the network for which

$$
z\left(t_{1}^{*}\right)=z((a b c d a))=20 \quad \text { and } \quad y\left(t_{2}^{*}\right)=y((a b c a c d a))=13
$$

6 - Zastosowania Matematyki 16.4 
2. The STSP has found application to many scheduling and sequencing problems, in some cases, however, there is a need to introduce more than one salesman.

Let us define the class of generalizations of the STSP as follows. We are given $n$ nodes $N=\{1,2, \ldots, n\}, m n$-dimensional square distance matrices $D^{k}=\left(d_{i j}^{k}\right)(k=1,2, \ldots, m)$ and the cost vector $C=\left(c_{1}, c_{2}, \ldots, c_{m}\right)^{\mathrm{T}}$. Let $\left\{t_{k}\right\}$ denote a family of subtours (i.e., closed paths) covering all $n$ nodes and let $N_{k}$ denote the set of nodes of $t_{k}(k=1,2, \ldots, m)$. We have

$$
\bigcup_{k} N_{k}=N .
$$

The problem is to determine subtours $\left\{t_{k}\right\}$ (i.e., also subsets $\left\{N_{k}\right\}$ such that one of the following optimality criteria is minimized:

$$
\begin{aligned}
& Z\left(\left\{t_{k}\right\}\right)=\sum_{k} L_{k}+\sum_{\left\{k: N_{k} \neq \varnothing\right\}} c_{k}, \\
& Y\left(\left\{t_{k}\right\}\right)=\max _{k} L_{k}+\sum_{\left\{k: N_{k} \neq \varnothing\right\}} c_{k},
\end{aligned}
$$

where $L_{k}$ is the length of $t_{k}$, and $c_{k}$ is the cost incurred if a salesman $k$ is actively used. The restrictions on subtours $\left\{t_{k}\right\}$ and/or subsets $\left\{N_{k}\right\}$ can be of the form

$$
\begin{gathered}
\left|N_{k}\right|>1, \\
N_{k_{1}} \cap N_{k_{2}}=\emptyset \quad\left(k_{1} \neq k_{2}\right), \\
\bigcap_{\left\{k: N_{k} \neq \varnothing\right\}} N_{k} \ni i^{*},
\end{gathered}
$$

(8) $t_{k}$ is the Hamiltonian cycle in $N_{k}$.

Basing on restrictions imposed on subtours $\left\{t_{k}\right\}$ and subsets $\left\{N_{k}\right\}$, and the form of the criterion we can formulate the following problems:

Problems 1, 2. For a number of subtours less than or equal to $m$. determine the feasible subtours $\left\{t_{k}\right\}$ satisfying (3), (5), (6) or (4)-(6).

Problems 3, 4. For a number of subtours less than or equal to $m$ determine the point $i^{*} \in N$ and the feasible subtours $\left\{t_{k}\right\}$ satisfying (3), (5), (7) or (4), (5), (7).

Problems 5, 6. For a fixed node $i^{*} \in N$ and a number of subtours less than or equal to $m$ determine the feasible subtours $\left\{t_{k}\right\}$ satisfying (3), (5), (7) or (4), (5), (7).

As particular cases of Problems 1-6 we can consider Problems 1'-6' in which the number of subtours $m$ is fixed.

In further Problems $\mathbf{1}_{\mathrm{H}^{-}} \mathbf{6}_{\mathrm{H}}$ and $\mathbf{1}_{\mathrm{H}^{-}}^{\prime} \mathbf{H}_{\mathrm{H}}^{\prime}$ restriction (8) is additionally imposed on the subtours $\left\{t_{k}\right\}$. 
In addition to the above problems we can formulate the whole series of other problems with many practical applications. For instance, we introduce the following additional requirements:

$1^{\circ}$ Assume that the $k$-th salesman can visit no more than (or exactly) $p_{k}$ nodes, i.e.

$$
\left|N_{k}\right| \leqslant p_{k}\left(\text { or }=p_{k}\right) \quad(k=1,2, \ldots, m) .
$$

$2^{\circ}$ We are given matrices $V^{k}=\left(v_{i j}^{k}\right)$ of the times of travelling. Let $T_{k}$ denote the length of $t_{k}$ under $V^{k}$. Then $T_{k} \leqslant s_{k}(k=1,2, \ldots, m)$, i.e., the time of travelling the $k$-th salesman is bounded by $s_{k}$.

For the sake of simplicity, the class of generalizations of the STSP can be characterized in terms of a five-tuple $\operatorname{GTSP}(\cdot / \cdot 1 \cdot 1 \cdot 1 \cdot)$, where the first parameter is the number of nodes, the second term is used to define the number of the subtours, the third term defines properties of subtours $\left\{t_{k}\right\}$, the fourth term describes properties of matrices $\left\{D^{k}\right\},\left\{V^{k}\right\}$ and of the vector $C$, and the last one defines the optimality criterion. For instance, the STSP can be characterized by $\operatorname{GTSP}(n / 1 /$ a tour $/ D / \Sigma)$, and, in virtue of Theorem 1 ,

$$
\operatorname{GTSP}(n / 1 / a \text { tour } / D \text { satisfies the triangle inequality } / \Sigma)
$$

is equivalent to

$$
\operatorname{GTSP}(n / 1 / \text { a Hamiltonian cycle } / D / \Sigma),
$$

etc. It is easy to see that $\operatorname{GTSP}(n / \leqslant n /(7) / D / \Sigma)$ is equivalent to $\mathrm{P} 1$ which, in turn, is equivalent to the STSP, and that $\operatorname{GTSP}(n / \leqslant n /(7) / T / \min \max )$ is equivalent to $\mathbf{P 2}$.

The STSP is an NP-complete problem, and so seem to be nearly all generalizations of it. It is interesting to note that GTSP $(n / \leqslant n /(6)$ and $(8) / D / \Sigma)$ is equivalent to the assignment problem which has an algorithm that runs in polynomial time, but a slight modification of the form

$$
\operatorname{GTSP}(n / \leqslant n /(6) \text { and }(8) / D, C / \Sigma+\Sigma)
$$

has no polynomial time algorithm, since the STSP is a special case of it, namely the STSP is equivalent to

$$
\operatorname{GTSP}\left(n / \leqslant n /(6) \text { and }(8) / D, C=\left(c_{1}, \infty, \ldots, \infty\right) / \Sigma+\Sigma\right) .
$$

There are some papers presenting the polynomial time transformations of some generalizations to the STSP for which many algorithms have been published. Unfortunately, these papers deal with problems which assume the same distance matrix for all salesmen.

The most wide class of generalizations of the STSP has been presented by Zak [12]. He has considered problems $1_{H^{-}}-6_{H}$ and algorithms for solving them by a branch-and-bound method. 
Some generalizations have found application to the problem of routing when there is more than one method of travelling, so that it is apparent that some generalizations are related to the multi-index problem.

Let us define one new notion to show the relations between some generalizations of the STSP and special cases of the multi-index problem. If problem $\mathrm{P}$ is to minimize $c(X)$ subject to $X \in A$ and problem $\mathrm{R}$ is to minimize $c(X)$ subject to $X \in B$, then $\mathrm{R}$ is called a relaxation of $\mathrm{P}$ if $B \supseteq A$. It is evident that if $X_{\mathrm{R}}^{*}$ and $X_{\mathrm{P}}^{*}$ are the optimal solutions to $\mathrm{R}$ and $\mathrm{P}$, respectively, then $c\left(X_{\mathrm{R}}^{*}\right) \leqslant c\left(X_{\mathrm{P}}^{*}\right)$. For instance, the AP is a relaxation of $\operatorname{GTSP}(n / 1 /(8) / D / \Sigma)$. Problem GTSP $\left(n / \leqslant n /(6)\right.$ and $\left.(8) /\left\{D^{k}\right\} / \Sigma\right)$ can be considered as a generalization of the $\mathrm{AP}$; the distance matrices are different for each subcycle of a solution, and the following problem is its relaxation:

Minimize

$$
\sum_{i=1}^{n} \sum_{j=1}^{n} \sum_{k=1}^{n} d_{i j}^{k} x_{i j}^{k}
$$

subject to

$$
\begin{gathered}
\sum_{k=1}^{n} \sum_{i=1}^{n} x_{i j}^{k}=1(j=1,2, \ldots, n), \quad \sum_{k=1}^{n} \sum_{j=1}^{n} x_{i j}^{k}=1(i=1,2, \ldots, n), \\
\sum_{i=1}^{n} x_{i j}^{k} \leqslant 1(j, k=1,2, \ldots, n), \quad \sum_{j=1}^{n} x_{i j}^{k} \leqslant 1(i, k=1,2, \ldots, n), \\
x_{i j}^{k} \geqslant 0 \quad(i, j, k=1,2, \ldots, n) .
\end{gathered}
$$

Similarly, the problem to minimize

$$
\sum_{i=1}^{n} \sum_{j=1}^{n} \sum_{k=1}^{m} d_{i j}^{k} x_{i j}^{k}
$$

subject to

$$
\begin{gathered}
\sum_{k=1}^{m} \sum_{i=1}^{n} x_{i j}^{k}=1 \quad\left(j=1,2, \ldots, n ; j \neq i^{*}\right), \quad \sum_{k=1}^{m} \sum_{i=1}^{n} x_{i i^{*}}^{k}=(\mathrm{or} \leqslant) m, \\
\sum_{k=1}^{m} \sum_{j=1}^{n} x_{i j}^{k}=1 \quad\left(i=1,2, \ldots, n ; i \neq i^{*}\right), \quad \sum_{k=1}^{m} \sum_{j=1}^{n} x_{i^{*} j}^{k}=(\mathrm{or} \leqslant) m \\
\sum_{i=1}^{n} x_{i j}^{k} \leqslant 1 \quad(j=1,2, \ldots, n ; k=1,2, \ldots, m) \\
\sum_{i=1}^{n} x_{i j}^{k} \leqslant 1 \quad(i=1,2, \ldots, n ; k=1,2, \ldots, m) \\
x_{i j}^{k} \geqslant 0 \quad(i, j=1,2, \ldots, n ; k=1,2, \ldots, m)
\end{gathered}
$$


is a relaxation of

$$
\operatorname{GTSP}\left(n / m(\text { or } \leqslant m) /(5),(7) \text { and }(8), i^{*} \text { is fixed } /\left\{D^{k}\right\} / \Sigma\right) .
$$

These relaxations are special forms of the problem of transportation by different methods, which, in turn, can be transformed to the multi-index problem.

3. Conclusion. Some comments on the STSP have been presented and the family of generalizations of the STSP has been described in this paper. It is rather unlikely that there exists a great number of generalizations which are not NP-complete. It would be of interest to find all "easy" generalizations and to find polynomial time transformations of generalizations to the problems for which some algorithms have already been developed.

It seems likely that the multi-index-like relaxations of the generalizations can be used in methods of solving in the way the AP is applied to solve the STSP. This approach needs an answer to the following question: how to eliminate unfeasible (for a given generalization) solutions of the corresponding relaxation, i.e., solutions which do not satisfy requirements imposed on the subtours.

Acknowledgement. The paper has partly been completed when the author was with the Department of Mathematical Engineering and Instrumentation Physics, Faculty of Engineering, University of Tokyo, Tokyo, Japan. The author is grateful to Professor Masao Iri for helpful discussion.

\section{Bibliography*}

[1] M. Bellmore and S. Hong, Transformation of Multisalesmen Problem to the Standard Traveling Salesman Problem, J. ACM 21 (1974), p. 500-504. $\operatorname{GTSP}\left(n / \leqslant m_{0}(\right.$ or $=m) /(5),(7),(8)$ and $i^{*}$ is fixed $\left./ D, C / \Sigma+\Sigma\right)$.

[2] N. Christofides, The Vehicle Routing Problem, R.A.I.R.O. Recherche Opérationnelle 10 (1976), p. 55-70.

VRP (the Vehicle Routing Problem) and others.

[3] - and S. Eilon, An algorithm for the Vehicle-dispatching Problem, Opl. Res. Q. 20 (1969), p. 309-318.

$\operatorname{STSP}, \operatorname{GTSP}\left(n / \leqslant n /(5),(7),(8)\right.$ and $i^{*}$ is fixed $\left./ D / \Sigma\right)$ and others.

[4] G. Clarke and J. W. Wright, Scheduling of vehicles from a central depot to a number of delivery points, Opns. Res. 12 (1964), p. 568-581.

GTSP $\left(n / \leqslant n /(7)\right.$ and $i *$ is fixed; the $i$-th node should receive $q_{i}$ and capacity of a carrier is limited $/ D / \Sigma)$.

\footnotetext{
- Bibliography contains all papers known to the author and concerning the generalizations of the STSP. The description of a generalization follows each paper،
} 
[5] G. B. Dantzig and J. H. Ramser, The Truck Dispatching Problem, Manage. ment Science 6 (1959), p. 80-91.

$\operatorname{GTSP}\left(n / \leqslant n /(7)\right.$ and $i^{*}$ is fixed, $i$-th node should receive $q_{i}$ and capacity of a carrier is limited $/ D / \Sigma)$.

[6] T. J. Gaskell, Bases for vehicle fleet scheduling, Opl. Res. Q. 18 (1967), p. 281-294. $\operatorname{GTSP}\left(n / \leqslant n /(7)\right.$ and $i^{*}$ is fixed; $i$-th node should receive $q_{i}$ and capacity of a carrier is limited $/ D / \Sigma)$.

[7] C. E. Miller, A. W. Tucker and R. A. Zemlin, Integer programming formulation of Traveling Salesman Problems, J. ACM 7 (1960), p. 326-329. $\operatorname{GTSP}\left(n / \leqslant m(\right.$ or $=m) /(5),(7),(8)$ and $i^{*}$ is fixed; $\left.(9) / D / \Sigma\right)$.

[8] C. S. Orloff, A fundamental problem in vehicle routing, Networks 4 (1974), p. 35-64. GRP, STSP, CPP.

[9] - Routing a fleet of $M$ vehicles to/from a central facility, ibidem 4 (1974), p. 147-162. $M-G R P, \operatorname{GTSP}\left(n /=m /(5),(7),(8)\right.$ and $i^{*}$ is fixed $\left./ D / \Sigma\right)$.

[10] - and D. Caprera, Reduction and solution of Large Scale Vehicle Routing Problems, Technical Report 75/TR-7, Princeton University, 1975. GRP.

[11] J. A. Svestk a and V. E. Huckfeldt, Computational experience with an mSalesmen Traveling Salesman Problem, Management Science 19 (1973), p. 790-799. $\operatorname{GTSP}\left(n /=m /(5),(7),(8)\right.$ and $i^{*}$ is fixed $\left./ D / \Sigma\right)$.

[12] Yu. A. Zak, Algorithms for solving the Travelling Salesman Problems, Cybernetics 1 (1974), p. 107-115. (Translated from Russian, Kibernetika 1 (1972), p. 99-106.)

Problems $\mathbf{1}_{\mathrm{H}^{-}} \mathbf{6}_{\mathrm{H}}$.

INSTITUTE OF INFORMATICS

UNIVERSITY OF WROCEAW

50-384 WROCEAW

Received on 23. 11. 1977

M. M. SYSLO (Wroclaw)

\section{UOGÓLNIENIA STANDARDO WEgo PROBLEMU KOMI WOJAŻERA}

\section{STRESZCZENIE}

Klasyczny problem komiwojażera (STSP) polega na wyznaczeniu najkrótszej drogi zamkniętej, przechodzącej przez wszystkie wierzchołki grafu, w którym każdemu połączeniu została przyporządkowana liczba - interpretowana jako długość połączenia. Jest to jeden z najtrudniejszych problemów optymalizacji kombinatorycznej, dla którego każda ze znanych metod rozwiązywania jest jedynie pewną odmianą ogólnego schematu postępowania, polegającego na niejawnym przeglądzie całego zbioru rozwiązań dopuszczalnych. Problem komiwojażera ma wiele zastosowań do szeregowania czynności, do wyznaczania optymalnych tras dla pojazdów czy wreszcie do konstrukcji systemów informacyjnych i został uogólniony na wiele różnych spo- 
sobów, tak aby mógł być stosowany do rozwiązywania rzeczywistych problemów z dodatkowymi ograniczeniami. Większość problemów, uważanych za uogólnienia klasycznego problemu komiwojażera, polega na wyznaczeniu optymalnych tras dla grupy komiwojażerów przy założeniu, że trasy spełniają pewne dodatkowe ograniczenia.

Jednym z celów tej pracy jest zdefiniowanie dość obszernej rodziny uogólnień klasyċznego problemu komiwojażera, kt6́ra zawiera wszystkie dotychczas rozpatrywane modyfikacje STSP. Pewne uogólnienia sa redukowalne do innych, w szczególności do STSP, ale tylko dla niektórych istnieją efektywne metody rozwiązywania. Końcowa część pracy zawiera relaksacje niektórych uogólnien STSP, będące wieloindeksowymi problemami transportowymi. 